medical advice averaged $6 \cdot 5$ months in the early years of the programme, whereas between 1936 and 1939 it was $5 \cdot 3$ months and in $19404 \cdot 6$ months. In $1932,31 \cdot 1$ per cent of the fatal cases had never been treated in a cancer hospital, while in 1940 this figure was reduced to $15 \cdot 6$ per cent, indicating that hospitalization for cancer is increasing far more rapidly than cases of the disease.

\section{Biology in Brazil}

WE welcome the appearance of No. 1 (March, 1942) of Vol. 2 of the Revista Brasileira de Biologia, the official organ of the Biological Society of Brazil. The issue runs to 133 pages and contains seventeen papers covering a very wide field of biological subjects including medicine and parasitology. Thus, P. W. Wygodzinsky describes new species of insects of the orders Diplura and Thysanura from Palestine : J. R. Valle and P. R. Souza discuss observations concerning the endocrine system of eighty-four ovoviviparous snakes, and especially the corpora lutea; and F. Feigl and H. Cardoso write on tests for the identification of ascorbic acid. Each volume of the journal is to contain about five hundred pages, comprised in four parts issued in March, June, September and December. The subscription outside Brazil is 4 U.S. dollars, which should be sent to the Secretario da Comissâo de Redaçâo, Mario Vianna Dias, Caixa postal 1.587, Rio de Janeiro, D.F., Brazil.

\section{Health of Ceylon}

According to the report of the Director of Medical and Sanitary Services, Ceylon, in 1940, malaria, as in previous years, was the most prevalent disease in the island, about 97,000 cases having been treated in hospitals and 2,994,000 in dispensaries. The chief outbreak occurred in the south-west early in May and continued until the middle of July. In the northwestern province an epidemic of dysentery, due to the Shiga bacillus, also started in May. During the year the leprosy survey which was begun in 1933 was completed. The total number of patients was 2,771 $-2,032$ males and 739 females-of whom more than a thousand were segregated in two leper asylums. The whole population of Ceylon is estimated at 5,951,000, The total births in 1940 numbered 212,982 , a rate of 35.8 per 1,000 ; deaths amounted to 122,738 , a rate of $20 \cdot 6$. The infant mortality-rate was 149 per 1,000 and the maternal rate $16 \cdot 1$.

\section{Aphids}

A shorT paper by G. Fox-Wilson ( $J$. Roy. Hort. Soc., 67, Pt. 6 ; June, 1942) reviews the horticultural significance and control of aphids. Eradication of these pests is often difficult, and one of the reasons is discussed in the paper. Viviparous stem mothers, when subjected to certain contact insecticides, often remain in a comatose state before death actually occurs, but living nymphs are often produced in this condition. Spraying with nicotine is the best control, but Derris and Pyrethrum washes should be employed where the plant parts attacked are to be used for food.

\section{Physics Bibliography}

THE vital importance of the library as a part of the equipment of a research laboratory is implicitly acknowledged in the Review of Scientific Instruments by the attention given to the current literature of physics in each number of the journal. Twice a year special book numbers are issued, and the spring book number (13, No. 4, April, 1942) contains twentyfour pages devoted to reviews of thirty-eight books on physics. In addition, a two-page "Condensed Library Guide for the Physicist" gives a summary of the standard sources of reference. Copies of the list for the use of students can be bought in quantity from the American Institute of Physics, 175 Fifth Avenue, New York. The list serves as a reminder of the extent to which physics lags behind chemistry in bibliography. The usual monthly survey, "Current Literature of Physics", deals with the research journals. The latest reference to an English journal appears to be that to the issue of NATURE dated February 7.

\section{Announcements}

Is pursuance of the decision of the Secretary of State for the Colonies to open the administrative service in the Gold Coast to Africans, Mr. K. A. Busia and Mr. A. L. Adu have been selected as assistant district commissioners in the Gold Coast. Mr. Busia, an Ashanti, was born in 1913. He was educated in the Gold Coast, where he graduated in 1939, and at University College, Oxford, where he obtained a B.A. degree. Mr. Adu, a member of the Twi tribe, was born in 1914. He attended schools in the Gold Coast, and afterwards went to Queens' College, Cambridge, where he took a degree in natural science.

THE following have been elected to fill vacancies which will occur on the Council of the Institution of Electrical Engineers on September 30 next : President, Prof. C. L. Fortescue; Vice-President, Mr. P. Good; Hon. Treasurer, Mr. E. Leete; Ordinary Members of Council, Prof. J. D. Cockeroft, Mr. A. J. Gill, Mr. D. B. Hoseason, Dr. A. H. Railing, Mr. E. A. Reynolds, Mr. H. W. H. Richards, Mr. J. M. Fleming and Mr. C. W. Bridgen.

AN extensive list of institutions, societies and research workers in the pure and applied plant sciences in Central and South America has been prepared by the editors of Chronica Botanica, in co-operation with the Division of Agriculture of the Office of the Co-ordinator of Inter-American Affairs, Washington, D.C. The list has been published in Chronica Botanica, 7, No. 2 and 3, March and May, 1942 (Chronica Botanica Co., Waltham, Mass.). There are about two thousand names in the list, which is the first of its kind.

Schuman's, of 20 East 70th Street, New York, have issued a catalogue entitled "Medical Miscellany List E". Attention may be directed to the following items: the "Compendium Artis Medicæ" of Bertucius alias Bertuccio or Bertrutius (1537), the "Libri duodecim" of Alexander of Tralles (1556), the "Opuscula anatomica" of Eustachius (1563-64), the first edition of John Hunter's "Treatise on the Venereal Disease" (1786), Morgagni's "De Sedibus et causis morborum" (1820-23), and various early works on anæsthesia. A section on military medicine contains notice of the following important works : George James Guthrie's "Commentaries on the Surgery of the War in Portugal, Spain, France and the Netherlands" (1862), Woodward's "Report on Epidemic Cholera, and Yellow Fever in the Army of the United States during the year 1867" (1868), George M. Sternberg's "Sanitary Lessons of the SpanishAmerican War" (1899), and Caband's "Chirurgiens et blessés à travers l'histoire" (1918). 